\title{
DOES MALACHI 1:2-3 TEACH DOUBLE PREDESTINATION?
}

\author{
Philip Suciadi Chia ${ }^{1)}$ Juanda $^{2)}$ \\ 1) Southern Baptist Theological Seminary - Kentucky USA \\ E-mail:pchia275@students.sbts.edu \\ ${ }^{2)}$ Evangelical Theological Seminary of Indonesia - Surabaya \\ E-mail: juanda@sttii-surabaya.ac.id
}

\begin{abstract}
The term 'double predestination' simply means that, just as God predestines some, but not all, to eternal salvation, so he predestines others to eternal punishment; this second part of 'double predestination', God's appointment of all but the elect unto eternal destruction, is sometimes called 'reprobation'; and those who are not the elect are thus called the 'reprobate'.The object of Malachi was in reminding the Jews that they were loved and chosen by God; it was, that he might the more amplify their ingratitude for having rendered such an unworthy reward for so great a favor of God: as he had preferred them to all other nations, he had justly bound them to perpetual obedience

With the inductive method, we will present a more objective truth of Scripture. We will not only explain the truth of the Bible would conclude (correct interpretation), but also accompanied by the evidence and arguments of the conclusions.

In conclusion, the meaning of hate in this context is God hated Esau, the absence of affection, because he is a sinful people therefore Yahweh opposed and kept distant from him (have no relationship). Based on this meaning, we can summarize that this verse (Mal. 1:3) doesn't teach about reprobation that God has predestined Esau to go to eternal destruction because Yahweh hated him beforehand but Lord indeed hated Edomites because they are sinful people.
\end{abstract}

Keywords: Double Predestination, Reprobation, Inductive Method, Scripture

\section{INTRODUCTION}

In the beginning of this article, I will provide a definition of double predestination and give a brief history about this doctrine. Hereafter, I will discuss regarding the supporting verse from Malachi 1:2 that was used by double predestination proponents to explain their thoughts and 
argumentations about this teaching. ${ }^{1}$

At the end, I will analyze that verse regarding to proper hermeneutic to interpret Malachi 1:2 well. The analysis, which I will use, towards this supporting verse will be based from its historical background of Malachi, the context (both immediate and broader context), grammatical verb, the analytical of love

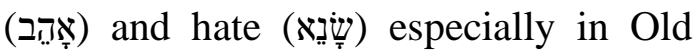
Testament nuance. I will use inductive method to get the right interpretation about those verses (Mal. 1:2-3).

The intention is the Holy Bible that gives the true understanding and the actual ideas and I will try to pull the ideas off from Holy Scripture itself (exegesis), not with deductive method that is trying to insert thinking ideas of human into the bible text (eisegesis). With the inductive method, I will present a more objective truth of Scripture. I will not only explain the truth of the Bible would conclude (correct interpretation), but also accompanied by the evidence and arguments of the conclusions. Thus, explanation of the truth of the Bible is not only based on the interpretation or assumption but also strongly supported by the context, historical, grammatical and theological.

\footnotetext{
${ }^{1}$ This is the view that God has determined the eternal destiny of every human being. He has chosen some to eternal life to be saved through the
}

approved previously.

\section{Definition of Double Predestination}

The term "double predestination" simply means that, just as God predestines some, but not all, to eternal salvation, so he predestines others to eternal punishment; this second part of "double" predestination, God's appointment of all but the elect unto eternal destruction, is sometimes called "reprobation"; and those who are not the elect are thus called the "reprobate".

Logically, the doctrine of reprobation is necessarily true if the following premises can be established: 1) God sovereignly chooses some men for salvation; 2) God does not choose all men for salvation; 3 ) there is no possibility of obtaining salvation apart from God's sovereign election thereunto. In other words, if God has chosen infallibly to save some, and has cut off any other means of salvation for all others, he has effectively made a choice concerning every person that has lived; he has chosen either to save him or to cut him off from all hope of salvation. Each of these premises may certainly be found in the bible; and so, it is

finished work of Christ, and foreordained others to everlasting punishment for their sin. 
Journal Didaskalia

E-ISSN: 2621-8054

P-ISSN: 2622-1667

manifest that God's eternal choice involves

the salvation of some and the damnation of others. $^{2}$

\section{A Brief History of Double}

Predestination.

R. Scott Clark pointed out that there is no one in Christian history except Augustine from Hippo (354-430) who has been known in such a way because of his doctrine about election and predestination like John Calvin (1509-1564). ${ }^{3}$ This is a remarkable fact because of various reasons. First of all, based on his work especially his third book of Institutio in which he gave explanations, argumentations and summary both formally and explicitly about predestination teaching. ${ }^{4}$ Secondly, history recorded that Calvin kept teaching this doctrine. Therefore, the influence of this teaching is continued to survive until now although there are a lot of polemics and controversies. ${ }^{5}$ One of the challenges of double predestination especially reprobation is in 529 A.D when Orange council firmly rejected this doctrine.

${ }^{2}$ http://www.monergism.com/thethreshold/articles/o nsite/qna/double.html

${ }^{3} \mathrm{R}$. Scott Clark, Institutes Calvin (Jakarta:

Momentum, 2009), 97.

${ }^{4}$ B.A Gerris, Grace and Gratitude: The Eucharistic Theology of John Calvin (Edinburgh: T\&T. Clark, 1993), 170.
However, in reality, Godescalc from Orbais (804-869), Ratramnus from Corbie and other supporters throughout medieval age in Church history were together to defend this teaching. ${ }^{6}$ Therefore, Clark summarizes that double predestination not only universal doctrine which has been taught but also the teaching for entire Christian community especially in sixteenth century. ${ }^{7}$

Warfield adds that Reformed theology has a lot of in common its teaching so that those similarities underlie and gave a shape and its power to all Reformation movements. Thus, there is no difference among the reformers regarding double predestination as Luther, Melanchthon and Butzer who were not less excited in inflaming this doctrine than Zwingli and Calvin. Even Zwingli cannot excel Luther in his sharp assertiveness regarding predestination teaching. In addition, Melanchthon also put predestination in official place in his scientific statements about Christian faith. ${ }^{8}$

Melanchthon's work about double

\footnotetext{
${ }^{5} \mathrm{R}$. Scott Clark, The Modern Calvin: John Calvin in Nineteenth and Twentieth Century Memory Cultures (Leiden: E. J. Brill, 2008).

${ }^{6}$ Russell L. Friedman, Commentaries on the Sentences of Peter Lombard (Leiden: Brill, 2002), 43.

${ }^{7}$ R. Scott Clark, Institutes Calvin, 100.

${ }^{8}$ Benjamin Warfield, Calvin and Calvinism (New

York: Oxford University Press, 1931), 357-58.
} 
predestination was poured out into his book "Loci Communes" which was published in 1521. In this book, Melanchthon stressed that Holy Scripture revokes human free will in predestination and everything which happens in this life not because plans and efforts of man but due to God's will. ${ }^{9}$ History also recorded that Luther supported double predestination doctrine in his book "De servo arbitrio" (bondage of the will) in 1525 .

This book was published and written in a response to Erasmus's reviews about Luther's teaching in predestination. ${ }^{10}$ Zwingli (1484-1531) also taught clearly that double predestination doctrine in treatise in 1530 with title on providence. ${ }^{11}$ In the era of Zwingli, there was Martin Bucer (1491-1551) who also Calvin's colleague in the defense of double predestination doctrine and wrote it into his thick book about Romans epistle. ${ }^{12}$ After Martin Bucer, there was Heinrich Bullinger (1504-1575), successor of Zwingli in Zurich, who has the same theological understanding in double predestination but slightly different in practical matters. ${ }^{13}$

\footnotetext{
${ }^{9}$ Wilhelm Pauck, Melachthon and Bucer (Philadelphia: Westminster, 1969).

${ }^{10}$ Martin Luther, Luther's Works (St. Louis: Concordia, 1958), 33.

${ }^{11} \mathrm{~W}$. P Stephens, The Theology of Huldrych Zwingli (Oxford: Oxford University Press, 1986), 97-107.
}

\section{The Supporting Arguments of Double Predestination in Malachi 1:2-3}

Calvin, one of the proponents of this doctrine, adduced that Malachi 1:2 is one of the strongest evidence that God has predestined human future either to be saved or perished beforehand (before Adam and Eve were created).

Holy Scripture states that "I have loved you," says the LORD. But you say, "How hast Thou loved us?" "Was not Esau Jacob's brother?" declares the LORD. "Yet I have loved Jacob (Mal 1:2 NAS). This verse surprises Calvin about God's love to Jacob. Calvin explained that his verse talks about God's rebuke to His wicked people because they didn't know how to grateful to Him. They didn't honor and fear Yahweh, God of Israel because they kept questioning God's love. ${ }^{14}$

The object of Malachi was in reminding the Jews that they were loved and chosen by God; it was, that he might the more amplify their ingratitude for having rendered such an unworthy reward

\footnotetext{
${ }^{12}$ Joel Edward Kok, The Influence of Martin Bucer on John Calvin's Interpretation of Romans (Durham: Duke University, 1993), 138.

${ }^{13}$ Cornelis P. Venema, Heinrich Bullinger and The Doctrine of Predestination (Grand Rapids: Baker Academic, 2002).

${ }^{14} \mathrm{http}: / /$ www.iclnet.org/pub/resources/text/m.sion/c vmal-01.htm
} 
for so great a favor of God: as he had preferred them to all other nations, he had justly bound them to perpetual obedience.

There is here mentioned a special favor - that the Lord took to himself the seed of Abraham, as it is said in the song of Moses that all nations are God's, but that he had cast his line to set apart Israel for himself (Deuteronomy 32:9). ${ }^{15}$ Though then the whole world was under God's government, it was yet his will to choose one family. If the cause be enquired, it is not to be found in men; for all were created from the earth, and souls were implanted in their bodies created from nothing.

Since it was so, we see that the difference arose from the fountain of gratuitous favor - that God preferred one race to the rest; and Moses often repeats this - that the Jews were not chosen because they were more excellent than other nations, but because God gratuitously loved their fathers. (Deuteronomy 7:7).

By love he means gratuitous favor. Malachi then does not consider here that the Jews had been chosen before other nations on the ground of their own merit; for if he granted this, they might have objected and said - "Why dost thou remind us that God has favored us more

${ }^{15} \mathrm{http}: / / \mathrm{www} . c c e l . o r g / c c e l / c a l v i n / c a l c o m 30 . p d f$ ${ }^{16} \mathrm{http} / / / \mathrm{www} . c c e l . o r g / \mathrm{ccel} / \mathrm{calvin} / \mathrm{calcom} 30 . \mathrm{pdf}$ than other nations, since he deemed us worthy, and rewarded our merit?"

But the Prophet takes it as admitted, according to what I have already said, that the Jews were by nature like other nations, so that their different condition did not proceed from themselves, or from their own worthiness, but from the gratuitous love of God. ${ }^{16}$ However, they had shaken off the yoke, and having despised God had given themselves up again to many corruptions. In short, the Jews paid him no reverence, he complains that he was defrauded of his right as a father; and as they entertained no fear for him. ${ }^{17}$ God could reply the Jews hardly because $\mathrm{He}$ created them and $\mathrm{He}$ is their father who gave them foods. He is the one who gives sun to shine every day for them and fruits in the land which bears its fruits even $\mathrm{He}$ bounds them with so many graces and goodness for them.

$\mathrm{He}$ also adopted them to be His children through Abraham's seed. Though, they still questioned His love and kept living in sins. ${ }^{18}$ Hence, there are two sins which Israel kept doing at that time. Firstly, they were forgetting God's kindness into their life and, secondly, they kept living in their sins which He rebuked in the book of

\footnotetext{
${ }^{17} \mathrm{http} / / /$ www.magister.msk.ru/library/bible/commen t/calvin/calvin 17.htm

${ }^{18}$ Ibid.
} 
Malachi. ${ }^{19}$

Despite of their wickedness, Calvin is amazed with God's election which has a lot of favor. He chooses Jacob (Israel) over their forgetfulness about His love and their iniquities $\mathrm{He}$ elects Jacob beyond Esau status as a firstborn and also his birthright. Esau should get his birthright because he is the oldest brother, but because of God has predestined Jacob from eternity that he is refused (Gen. 25:23). ${ }^{20}$

God chooses them to be His people not because of their merit or goodness but His great love only. Deuteronomy 9:6 also restates that God elects Israel among other nations not because of their righteousness but because He knows since the beginning that Israel is rebel, stubborn and stiffnecked people. In the context of Malachi, Calvin concluded that Jacob's election and Esau's rejection are because God's own will not because of human merit. ${ }^{21}$

Then follows a proof of hatred as to Esau, the Lord made his mountain a desolation, and his inheritance a desert where serpents dwelt. Esau, we know, when driven away by his own shame, or by his father's displeasure, came to Mount Seir; and the whole region where his

\footnotetext{
${ }^{19}$ John Calvin, Calvin: Commentaries (Grand Rapids, MI: Christian Classics Ethereal Library, 1958), 199-202.

${ }^{20}$ Ibid.
}

posterity dwelt was rough and enclosed by many mountains. But were any to object and say, that this was no remarkable token of hatred, as it might on the other hand be said, that the love of God towards Jacob was not much shown, because he dwelt in the land of Canaan, since the Chaldeans inhabited a country more pleasant and more fruitful, and the Egyptians also were very wealthy; to this the answer is - that the land of Canaan was a symbol of God's love, not only on account of its fruitfulness, but because the Lord had consecrated it to himself and to his chosen people.

So Jerusalem was not superior to other cities of the land, either to Samaria or Bethlehem, or other towns, on account of its situation, for it stood, as it is well known, in a hilly country, and it had only the spring of Siloam, fiom which flowed a small stream; and the view was not so beautiful, nor its fertility great; at the same time it excelled in other things. for God had chosen it as his sanctuary; and the same must be said of the whole land. As then the land of Canaan was, as it were, a pledge of an eternal inheritance to the children of Abraham, the scripture on this account greatly extols it, and speaks of it in

\footnotetext{
${ }^{21} \mathrm{http}: / / \mathrm{www}$. iclnet.org/pub/resources/text/m.sion/c vmal-01.htm
} 
magnificent terms. If Mount Seir was very wealthy and replenished with everything delightful, it must have been still a sad exile to the Idumeans, because it was a token of their reprobation; for Esau, when he left his father's house, went there; and he became as it were an alien, having deprived himself of the celestial inheritance, as he had sold his birthright to his brother Jacob. This is the reason why God declares here that Esau was dismissed as it were to the mountains, and deprived of the Holy Land which God had destined to his chosen people. ${ }^{22}$

But the Prophet also adds another thing, — that God's hatred as manifested when the posterity of Esau became extinct. For though the Assyrians and Chaldeans had no less cruelly raged against the Jews than against the Edomites, yet the issue was very different; for after seventy years the Jews returned to their own country, as Jeremiah had promised: yet Idumea was not to be restored, but the tokens of God's dreadful wrath had ever appeared there in its sad desolations.

Since then there had been no restoration as to Idumea, the Prophet shows that by this fact the love of God towards Jacob and his hatred towards Esau had

22 http://www.ccel.org/study/Malachi_1\%3A23 ? version $=$ niv $\&$ tab $=$ commentary $\&$ commentary $=1$ been proved; for it had not been through the contrivance of men that the Jews had liberty given them, and that they were allowed to build the temple; but because God had chosen them in the person of Jacob, and designed them to be a peculiar and holy people to himself. ${ }^{23}$

But as to the Edomites, it became then only more evident that they had been rejected in the person of Esau, since being once laid waste they saw that they were doomed to perpetual destruction. This is then the import of the Prophet's words when he says, that the possession of Esau had been given to serpents. ${ }^{24}$ This is a double predestination teaching. Also, Voluntarism role is prominent in Calvin's interpretation who says that human cannot satisfy God. Therefore, if man is elected or rejected it because God's will only.

R.C Sproul also states that The bible is clear that just as God chooses some for mercy and salvation, he chooses others for judicial hardening and reprobation: when he loved Jacob, even before his birth, he also hated Esau at the same time (Rom. 9:10-13); when he chose to save Israel from Egypt for the glory of his grace, he also chose to raise up Pharaoh in hardened

\footnotetext{
${ }^{23} \mathrm{http} / / /$ www.ccel.org/study/Malachi_1\%3A23 ? version $=$ niv $\&$ tab $=$ commentary $\&$ commentary $=1$ ${ }^{24}$ Ibid.
} 
rebellion, for the glory of his wrath (Rom. 9:17-18); and in fact, he does this with all men, choosing from the same lump of human clay some to make into vessels of honor and some to make into vessels of dishonor, in order to show by the one class the glory of his mercy and by the other class the glory of his judgment and wrath (Rom. 9:21-23). Nor is it just the apostle Paul who speaks to this issue so clearly: Peter also speaks of those to whom Christ is the precious Cornerstone of salvation and those who stumble against him to their eternal destruction; and of those who are reprobate, he says clearly that they were "predestined" to disobey the word and so to perish (1 Pet. $2: 6-8){ }^{25}$

\section{Critical Analysis Towards Double} Predestination In The Book of Malachi 1:2-3

In Malachi 1:2 the bible written "I have loved you," says the Lord. But you ask, 'How have you loved us?' "Was not Esau Jacob's brother?" declares the Lord. "Yet I have loved Jacob. Calvin conclude from this verse that God chosen His people

\footnotetext{
${ }^{25} \mathrm{http}: / / \mathrm{www} \cdot$ the-

highway.com/DoublePredestination_Sproul.html

${ }^{26}$ John Calvin, Calvin: Commentaries (Grand Rapids, MI: Christian Classics Ethereal Library, 1958), 234.
}

(Israel) not based on worthiness, goodness or status but only because His love that is great. Not only that, even refusal of Esau because of the Lord's will not base on mankind will itself ${ }^{26}$. According to Calvin, this is double predestination.

\section{Historical Background of Malachi}

Gleason Archer gave the based background of the book of Malachi very well. He explained that considering internal fact, clearly visible that his prophecies in the second half of the $5^{\text {th }}$ century, most probably in 435 S.M. The facts is that the Holy Temple (altar) has been built again and the sacrifice place according to the custom of Moses has been held again $(1: 7,10 ; 3: 1)$ and a Persian governor was in power at that time; therefore not possible on one of Nehemiah time (445 and 433 S.M.) ${ }^{27}$.

Based on these facts there are two reasons for the nation of Israel made a statement saying 'How have you loved us?' (Mal. 1:2b). The first reason is because the decline level of their spiritual life, so, they say it. God's love was obvious and clear to them but they are not aware because they

\footnotetext{
${ }^{27}$ Archer, Gleason L, Jr., A Survey of Old Testament Introduction (Chicago: Moody Press, 1964), 670.
} 
are eyes are spiritually blind. ${ }^{28}$ The second reason is the disappointment of Israel because they have felt the banishment and destruction of the land of Judah. The absence of the king who ruled over them and their temple which had been built at the time of Solomon were not more to make them little hope of the prophecies that the nation of Israel will be restored. ${ }^{29}$ Because of these things, Israel asked 'How have you loved us?' When viewed from the life course is still unstable and everything is still very difficult because once from exile. 30

God listened to their complaints, interesting that God did not rebuke Israel, and provide answers to their complaints. Thus, the spiritual state of the weak and poor of their lives became the background of the Israeli complaint. In short, form historical background, the readers may know that these verses are not discussing about double predestination, final destiny (heaven or hell), of Israelites and Edomites but rather current state of those nations.

The Meaning of Love (אהב) and Hate (שנא)

Nevertheless, God answered them

\footnotetext{
28 Ibid.

${ }^{29}$ Kevin J. Vaanhoozer, Theological Interpretation of the Old Testament (Grand Rapids: Baker Book House, 2005), 890.
}

by saying, "Was not Esau Jacob's brother, but I loved Jacob and hated Esau" (Malachi 1:2 b-3a). The word love (אהב) contrasted with hate (שנא). The intensity of the meaning ranges from God's infinite affection for his people to the carnal appetites of a lazy glutton. ${ }^{31}$ In summary, the word "love" in this verse can be understood as God's infinite affection (love) for his people although they were disobedient nation.

The term 'hate' has the same meaning in Ugaritic. The verb saneh, and its derivatives have the root meaning "to hate." It expresses an emotional attitude toward persons and things which are opposed, detested, despised and with which one wishes to have no contact or relationship. It is therefore the opposite of love.

Whereas love draws and unites, hate separates and keeps distant. The hated and hating persons are considered foes or enemies and are considered odious, utterly unappealing. God's hatred for idols and feasts is also directed against people, e.g, Esau (Mal 1:3; Gen 27:1; Ps 5:6*; Ps 11:5).

In each case the character and/or

\footnotetext{
${ }^{30}$ Bill T. Arnold and Bryan E. Beyer, Encountering the Old Testament: A Christian Survey. (Grand Rapids: Baker Book House, 1999), 512.
}

${ }^{31}$ TDOT, 99-117. 
activities of the hated ones are expressed; thus God is opposed to, separates himself from, and brings the consequences of his hatred upon people not as mere people, but as sinful people. The OT speaks a number of times of men hating God. Men express in one way or other an absence of love and kindly sentiment or actual illwill and aversion toward God (Ex 20:5; Deut 5:9; 2 Chron 19:2; Ps 22:8) ${ }^{32}$

In conclusion, the meaning of hate in this context is God hated Esau, the absence of affection, because he is a sinful people therefore Yahweh opposed and kept distant from him (have no relationship). Based on this meaning, we can summarize that this verse (Mal. 1:3) doesn't teach about reprobation that God has predestined Esau to go to eternal destruction because Yahweh hated him beforehand but Lord indeed hated Edomites because they are sinful people.

\section{Context Broader Context}

Allen Ross so well argued that Jacob was chosen and Esau rejected cannot be separated from Genesis 25:23, the choice is of a nation is not personal. ${ }^{33}$ Moreover, based on interpretation of the meaning of

\footnotetext{
32 Theological Wordbook of The Old Testament.

${ }^{33} \mathrm{http} / / /$ bible.org/seriespage/god\%E2\%80\%99s-

faithful-covenant-love-malachi-11-5.

${ }^{14}$ Ibid.
}

the word, the selection or rejection in this passage is not too meaningful double predestination, as Calvin argued but more a providential.

This is why Paul also argues this in Romans 9:13 as an example of divine choice. Furthermore, Allen Ross explains that God's love for Jacob is a special love. The point is that the lineage of Jacob (Israel) who has been chosen for a special purpose in the world is to be a channel of blessing to the nations, and gave birth to the Messiah. ${ }^{34}$

The Edomites, descendants of Esau, was not chosen or rejected. According to Allen Ross, this does not mean that individuals of the Edomites cannot come to faith in God but merely the lineage of Esau rather than the line choice for the Messiah. Therefore, the rejection and selection has nothing to do with spiritual salvation but merely to be a blessing and a descendant of the forerunner of the Messiah.

Therefore, Malachi 1:3 doesn't talk about Esau's destiny as an individual nevertheless as a nation and doesn't imply about eternal punishment. So, what does Malachi say about Edomites destiny?

\footnotetext{
${ }^{15}$ Harrison, Roland Kenneth, Introduction to the Old Testament (Grand Rapids: William B. Eerdmans Publishing Co., 1969), 783
} 


\section{Immediate Context}

Based on Malachi context, the rejection of God to Edom (Esau) did not result in the destruction of the spiritual but the physical life (Malachi 1:3-4) ${ }^{35}$ So here it is not only the rejection of predestination as Calvin thought the punishment of eternal punishment in the world but for Edom. Based on historical, God's judgment cannot be separated from the historical background. ${ }^{36}$

The destruction of physical life is also supported by Amos who noted that the crimes of Edom was because he was pursuing his brother (Israel) itself by the sword, restrain compassion, harbored anger for good and permanently store frustration (Amos 1:11). Not only that, Obadiah also rebuked the evil of Edom against Judah, which is let yourself were looted even when Jerusalem also attacked Judah. Judah, Edom is not helping on the day of his troubles, but underestimate even rejoice in the suffering of his brother. Edom is the culmination of $\sin$ when he also killed the people of Judah who escaped from the attack and capture those who fled (Ob. 1:11-14) ${ }^{37}$.

\footnotetext{
${ }^{36}$ John H. Sailhamer, Introduction to Old Testament Theology (Grand Rapids: Zondervan Publishing House, 1995), 835,
}

God punishes, by using the word hate, cannot be separated from the background of the wicked Edom against the nation of Israel (Amos) and Judah (the book of Obadiah). Thus, the rejection and selection has nothing to do with spiritual salvation but merely to be a blessing and a descendant of the forerunner of the Messiah. Consequently, here it is not only the rejection of predestination as Calvin thought the punishment of eternal punishment in the world but for Edom.

In summary, Malachi was not talking about double predestination as Calvin lay out based on the evidence historical background, context, both broader and intermediate, and meaning of the words (love and hate).

\section{REFERENCE}

[1] Archer, Gleason L, Jr. A Survey of Old Testament Introduction. Chicago: Moody Press, 1964

[2] Arnold, Bill T. and Bryan E. Beyer. Encountering the Old Testament: A Christian Survey. Grand Rapids: Baker Book House, 1999.

[3] Calvin, John. Calvin: Commentaries. Grand Rapids, MI: Christian Classics

\footnotetext{
${ }^{37}$ Unger, Merrill F., Introductory Guide to the Old Testament, (Grand Rapids: Zondervan Publishing House, 1951), 676.
} 
Ethereal Library, 1958.

[4] Chia, P. S., \& Juanda, J. (2019). A

Hebrew Exegesis Of Isaiah 62: 1-5 The

Restoration Of Zion. Journal

KERUGMA, 2(2), 57-66.

[5] Chia, P. S., \& Juanda, J. (2020).

Penafsiran Amilenialisme \& Teologi

Kovenan Dalam Memahami Alkitab.

Journal Kerusso, 5(2), 1-23.

[6] Clark, R. Scott. Institutes Calvin.

Jakarta: Momentum, 2009.

[7] The Modern Calvin:

John Calvin in Nineteenth and Twentieth

Century Memory Cultures. Leiden: E. J.

Brill, 2008.

[8] Friedman, Russell L. Commentaries

on the Sentences of Peter Lombard.

Leiden: Brill, 2002.

[9] Gerris, B.A. Grace and Gratitude: The

Eucharistic Theology of John Calvin.

Edinburgh: T\&T. Clark, 1993.

[10] Harrison, Roland Kenneth.

Introduction to the Old Testament. Grand

Rapids: William B. Eerdmans Publishing Co., 1969.

[11]Http://bible.org/seriespage/god\%E2\% 80\%99s-faithful-covenant-love-malachi$11-5$

[12]Http://www.ccel.org/ccel/calvin/calco m30.pdf

[13]Http://www.iclnet.org/pub/resources/t ext/m.sion/cvmal-01.htm

[14]Http://www.magister.msk.ru/library/b ible/comment/calvin/calvin17.htm

[15]Http://www.monergism.com/thethresh old/articles/onsite/qna/double.html [16] Http://www.the-

highway.com/DoublePredestination_Spro ul.html

[17] Kok, Joel Edward. The Influence of

Martin Bucer on John Calvin's

Interpretation of Romans. Durham: Duke University, 1993.

[18] Luther, Martin. Luther's Works. St.

Louis: Concordia, 1958.

[19] Pauck, Wilhelm, Melachthon and

Bucer. Philadelphia: Westminster, 1969.

[20] Sailhamer, John H. Introduction to

Old Testament Theology. Grand Rapids:

Zondervan Publishing House, 1995

[21] Stephens, W.P. The Theology of

Huldrych Zwingli. Oxford: Oxford

University Press, 1986.

[22] Unger, Merrill F. Introductory Guide to the Old Testament. Grand Rapids:

Zondervan Publishing House, 1951.

[23] Venema, Cornelis P. Heinrich

Bullinger and The Doctrine of

Predestination. Grand Rapids: Baker

Academic, 2002.

[24] Vaanhoozer, Kevin J. Theological

Interpretation of the Old Testament.

Grand Rapids: Baker Book House, 2005.

[25] Warfield, Benjamin. Calvin and

Calvinism. New York: Oxford University

Press, 1931. 